\title{
Körömi Gábor
}

\section{Tábori szabadidős játékaink}

A magyar drámapedagógiai szakirodalomban sokszor említik kiindulási pontként a nagy közép-európai pedagógus, Comenius nevét. Ám a szokásos citátum (,...minden, ami a nyilvánosság elótt...”) helyett hadd idézzek egy talán még fontosabb jótanács-gyújteményt, melyet a sárospataki pedagógus a játékok alkalmazásáról ir, Schola Ludus munkájában. „Allítom, hogy ami a játékban gyönyörúséget okoz, az elóször is a mozgás. (...) a másik gyönyörködtetô elem az önkéntességból származik... harmadszor a társaság okozza... negyedszer a versengés... ötödször a rend... a hatodik, ami a játékokat vonzóvá teszi, megtanulásuknak az a könnyú módja, mely tisztán példákból és utánzásból, és semmi vagy csak nagyon kevés elméleti tudnivalóból áll, ami alkalmasint szüremlik csak beléjük. S végül a játék kedveli a pihenést is... a szórakozáshoz akkor kellemesebb a visszatérés, ha szüneteket iktatunk közbe" (Comenius, 1999, 103-105. o.). Nyári táborozásról, tábori hagyományokról szóló dolgozatnak ennél szebb mottója nem is lehetne.

\section{Bevezetés}

A pedagógiai szakirodalom a szabadidős tevékenységek között is csak megtürt gyermekként tesz említést a táborozásról. Hiszen a szabadidő intenzív eltöltése ezen a felületen követhető és rögzíthető a legjobban. A táborok zárt ideje és évről évre szóló hagyományai sok ezer gyermeknek határozhatják meg a gyermekkorát, fontos szerepet tölthetnek be felnőtté válásukban is. Ennek ellenére a pedagógiai folyóiratokban is meglehetösen kevés említést találni erről a területről. Talán a nyári táborokhoz kötődő ideológiai háttértartalom miatt? Vagy éppen a táborozás mint szabadidős közösségi tevékenység iskolán kívülisége, saját belső szabályrendszere tesz minden tábort egyedivé, így kevésbé mérhetővé.

Hétköznapi életünk egyik meghatározó része diákként és pedagógusként egyaránt a nyári szünet. Pedagógiai szempontból ennek legfontosabb része a táborozás. Sokféle táborozási formával találkozhatunk, tematikus vagy iskolai, elmenős vagy napközis tábor, legutóbb találkoztam a vándortáborozást újraélesztő kezdeményezéssel is. Közös bennük, hogy az együtt töltött idő intenzitása, a tábor időbeli és térbeli zártsága másféle pedagógusmagatartást, így másféle nevelési helyzeteket kínál, mint a hétköznapi, iskolai tevékenységek. Trencsényi László szerint az iskola kitüntetett szerepe az új generációk nevelésében megszünt (Trencsényi, 20I7), bár a nevelés egyik fontos helyszíne maradt, mellette nagyon sok olyan kortárs hatás erősödött meg, melyben a szabadidő eltöltése hatékonyabb, hatásosabb nevelési helyzeteket eredményez, mint a hagyományos iskola.

Az egyik ilyen alternatív terület a táborozás. A felnőtt táborozók visszaemlékezéskor számos esetben bevallják, hogy az adott életszakaszban meghatározóbb élményt, emléket őriznek a megélt nyári táborozásról, mint a túlélt tanévről (Farkas, 1992). A Marczibányi Téri Mủvelődési Központ tematikus táboraiban vagy az általam megélt színjátszó táborokban is a résztvevők sokszor nyári tábortól nyári táborig számolták az időt. A kapcsolatok, barátságok nemcsak a tábor ideje alatt, hanem utána évekig, évtizedekig megmaradnak egymás között a kortárs közösségben ugyanúgy, mint a felnőttek és a gyerekek között. 
Gyerekként Kaposi László táboraiban, ifiként az elmaradhatatlan színjátszótáborok mellett saját iskolám vándortáboraiban, csoportvezető tanárként, táborvezetőként Szakall Judit müvészeti táboraiban vehettem részt. Kollégáimmal szerveztünk Harry Potter-tábort, müvészet-természet tábort és számos tematikus napközis tábort. Mindannak, amit a táborozásról írok, elsősorban saját élményeim, tapasztalataim képezik alapját.

A Magyar Drámapedagógiai Társaság nyári módszertani rendezvényén, a SpártaDráma 2007-es programján kollégáimmal összegyüjtöttük legkedvesebb, legjobb tábori játékainkat, ötleteinket, az akkori gyűjtés eredménye megjelent a társaság periodikájában, a Drámapedagógiai Magazinban (Körömi, 2007). Időközben megjelent Szakall Judit Táborozás című könyve, melyben összefoglalja a „marczis táborok” tapasztalatait (Szakall,

Egy jó tábor elindithat, kinyithat, pályára állithat tehetségeket, az együtt átélt élmények meghatározóak lehetnek valamennyi résztvevónek nemcsak egyénileg, de a közösségi lét szempontjából is. Osztályközösségek, szinjátszó csoportok erôsödhetnek meg az együtt töltött idóben, barátságok alakulhatnak ki, melyek egy életre vagy legalább évekre meghatározóvá váltak. Egyénileg is kaphat annyi megerósitést a tábor ideje alatt a részt vevó gyermek, hogy megerósödve, célokat találva lásson neki az új tanévnek. A tábor mint nevelési szintér sokféle helyzetet kinál. 20I2). 20I3-ban tehetséggondozó tábort szerveztem Lengyelben, melynek szervezési tapasztalatairól szintén írtam összefoglalót (Körömi, 20I3). Az elmúlt években számos müvészeti tábort, napközi táboros foglalkozást szerveztünk munkatársaimmal Csepelen, a Nagy Imre ÁMK-ban. Ezen a nyáron pedig részt vehettem a Kecskeméti Ifjúsági Otthon Fantázia Táborában, Parádon, melyről szintén jelent már meg módszertani összefoglaló (Józsa és Tegyi, 20II). Lassan összeáll a kutatható szakirodalom, a táborban használható nagy játékok leírásaival. A sokféle közösségben használható, közösségépítő szabályjátékok számos játékgyüjteményben megtalálhatók, ezért most kifejezetten azokra a játékokra, keretjátékokra igyekszem koncentrálni, melyek föképp tábori körülmények között müködnek.

Egy jó tábor elindíthat, kinyithat, pályára állíthat tehetségeket, az együtt átélt élmények meghatározóak lehetnek valamennyi résztvevőnek nemcsak egyénileg, de a közösségi lét szempontjából is. Osztályközösségek, színjátszó csoportok erősödhetnek meg az együtt töltött időben, barátságok alakulhatnak ki, melyek egy életre vagy legalább évekre meghatározóvá váltak. Egyénileg is kaphat annyi megerősítést a tábor ideje alatt a részt vevő gyermek, hogy megerösödve, célokat találva lásson neki az új tanévnek. A tábor mint nevelési színtér sokféle helyzetet kínál. Elsőként természetesen a hagyományos - pedagógus - diák kapcsolatot kell említenem, melyben nem csak az adott foglalkozások, hanem a reggeli ébredéstől a közös étkezésen át a takarodóig számtalan új extracurriculáris pedagógiai tartalom, nevelési helyzet található. Másodszor kell említenünk a saját közösség nevelö erejét, hiszen a 24 órás együttlétben, „összezárva” egymást is nevelik, segítik a részt vevő gyerekek. A tábor életébe való beletanulásban, az egyes szokások, játékok szabályainak átadásában, megtanításában a régi táborozók is fontos szerepet töltenek be. Így azokban a táborokban, ahol a megnőtt, ,ifi” korba került fiatalok kezét nem engedik el, hanem feladatokkal látják el őket, kialakul valamiféle kortárs segítő helyzet is. A kisebb nehézségeket, a napi rutinnal kapcsolatos feladatokat, a közösség problémáit, első körben nem a „felnőttek”, hanem az „ifik" igyekeznek megoldani. Teszik ezt természetesen felnőtt jóváhagyással, felügyelettel, ugyanakkor magukat egyre komolyabb pedagógiai szerepben kipróbálva, mely a pedagóguspálya felé vezető út meghatározó állomása lehet, mint e sorok írójának életében 
történt. A legfontosabb ezekben a helyzetekben számomra a mintaadás, mely az indirekt pedagógia egyik legfontosabb nevelési eszköze (Trencsényi, 2006).

„A közvetett (indirekt) hatásrendszer forrása (ezzel szemben) a közösség tevékenysége, az ezen belül kialakított feladatok rendszere, valamint a közösségi tevékenység keretében kibontakozó egyéb, sok esetben »tapasztalati« jellegünek nevezett hatások, amely utóbbiakat maguk a közösség tagjai produkálják igen változatos kölcsönhatások, interakciók formájában" (Bábosik, 2004, I00. o.). Az indirekt nevelés különösen fontos területe a szabadidős tevékenység, ennek neveléstani hatása jelentős és bizonyított. A szabadidős tevékenységek közben a gyerekek a minta megtapasztalásával, a tevékenységek átvételével, indirekt eszközökkel sajátítják el a szabálykövetés, az együttmüködés, a szolidaritás, a felelösségvállalás stb. erényeit, úgy téve mindezt, hogy nem iskolai tevékenységeket végeznek, hanem „csak” játszanak (Trencsényi, 1992). Az indirekt neveléshez nagymértékben kötődő reformpedagógiai irányzatok és a nyári táborok kapcsolata is nyilvánvaló. Az általam ismert gyermekszínjátszó táborokban használt módszerek többet merítettek a reformpedagógiai irányzatokból, mint a hagyományos iskolai életből. Ennek egyik oka természetesen a táborok önkéntes jellege, hiszen ha nem tetszett a gyerekeknek a program, akkor a következő évben már nem jöttek el. Másrészt a tábort szervező pedagógusok nyitottsága és reformpedagógiai tájékozottsága is fontos szerepet játszott a táborok pedagógiai módszertanának kialakulásában.

Az alábbi gyüjtemény nem szabálygyüjtemény szeretne lenni, ezért a leírások sem a teljességre törekvő játékmagyarázatok. Sokkal inkább emlékeztetők, ötletezések, melyből az olvasó - jövendőbeli játékszervező - feladata, hogy megtalálja, kitalálja az ötletek felhasználásával, adaptálásával a saját játékait.

\section{A cserkészettől a müvészeti táborokig}

Lord Baden-Powell, a cserkészmozgalom angliai megalapítója eredetileg a csellengőknek kínált szabályrendszert, ifjúkori szerepet, játékot, s ezzel elfoglaltságot, szabadidős tevékenységet, s tegyük hozzá, erkölcsi és ideológiai nevelést is. Az ifjúsági mozgalmak hamar felismerték, hogy az iskolaidőn túl, szabadidőben, nyári szünetben is programot kell szervezniük tagjaiknak. A cserkészet és az utána kialakult más ifjúsági mozgalmak nyári tevékenysége számos játékgyüjtemény és tábori ajánló elkészítését ihlette. A heti rendszeres tevékenységek mellett nagyon fontos szerep jut a mozgalmi életben a nyári találkozásoknak, amikor nemcsak egy foglalkozás erejéig, hanem éjjel-nappal együtt voltak a fiatalok, s az együttélés közben elsajátították mindazokat a szabályokat és erényeket, melyet otthon vagy az iskolában nem sikerült (Bodnár, 1989). A mozgalom Magyarországon is hamar népszerü lett, elsősorban a középiskolába járó fiatalok között.

A cserkészek után jöttek az úttörök, miután az előbbiek müködését a hatalom ellehetetlenítette. A szovjet mintára átvett gyerekmozgalom része volt az iskolai ideológiai és pedagógiai nevelőmunkának, lényegében ezt egészítette ki, erősítette meg a foglalkozásokon és a táborokban. Mégis, az úttörőmozgalom sokat átvett a cserkészet örökségéből. A hadijáték elemei, az akadályversenyek keretjátéka, az egyes tábori játékok, dalok is hasonlítottak egymásra. A táborozás mint ideológiai eszköz és praktikus ismeretátadó helyzet az úttörőknél sem maradt csak ideológiai fegyver, számos játék, átvett vagy újra kitalált hagyomány kötődött, kötődik hozzá. A hetvenes évek végén az úttörőtáborok megújításán fáradozva szerveztek tematikus müvészeti táborokat Csillebércen lelkes pedagógusok és népmúvelök (Trencsényi és Papp, I98I), melyekben a müvészet, a történelem és a hagyomány egybefonásával tették le a későbbi komplex müvészeti programok alapjait (Trencsényi, I992). Az elmúlt időszakban került hozzám az úttörőmozgalom egyik fontos kiadványa, az Úttörővezető majdnem összes bekötött évfolyama. Ebben 
számos módszertani ismereteket, tábori játékot és praktikus ismeretet gyüjtöttek össze, a májusi számok rendszeresen tábori tematikus lapszámként készítették elő a következő nyarat (pl. Úttörövezető, I983, I985). A rendszerváltás előtti évek tábori összefoglalói közt mindenképpen érdemes megemlíteni Leveleki Eszter bánki táborait (Farkas, I992). Pipecland neves és névtelen polgárainak beszámolóiból kiderül, hogy a pedagógus-diák közösség minta gyermekköztársaságot alapított egy olyan társadalomban, amire a valódi demokrácia kevésbé volt jellemző, így a gyerekek a hivatalos iskolarendszeren kívül próbálhatták ki a demokratikus társadalmat.

Nagyon fontos hangsúlyozni a tábori létezés iskolán kívüli helyzetét - még a hagyományos iskolai táboroknál is fontos különbséget tenni az iskolai idő és a tábori idő között. Nemcsak a 24 órás pedagógus-gyermek együttlét miatt, hanem az alapvetően önkéntes és szabadidős tevékenységek nagy száma miatt is. Sokszor ezek a helyzetek hatékonyabb és emlékezetesebb nevelési eredményeket produkáltak, mint a hagyományos iskolai programok. A forma, hogy egy időre vonuljunk ki a világból, hozzunk saját szabályokat, igyekezzünk azokat betartani, és úgy eltölteni az időt, hogy azt mindenki hasznosnak érezze, elképesztő mennyiségü és minőségű tábori lehetőséget hozott létre. A rendszerváltásig elsősorban mozgalmi keretek között, majd utána a fizetöképes kereslet igényeit figyelembe véve szinte minden szabadidős tevékenységben létezik nyári tábor is, az évközi elfoglaltságok zárásaként, az új tanév előkészítéseként. Sportolóknál vált be az edzőtábor kifejezés, ugyanakkor egyes múvészeti ágaknál, pl. a színjátszásban is, megjelenik ez a forma. Az intenzív nyári együttlét egy színjátszó közösség életében hónapokkal viheti elöre a csoportot, az egész év alapjait teheti le. Próba délelőtt, délután, este, tábor végén bemutatóval - számomra ezek az intenzív „munkatáborok” élményt, az alkotás és az önkifejezés élményét jelentették. Ehhez azonban fontos a motiváltság és az elköteleződés, hiszen ezek híján ez a forma nem müködik. Jelen dolgozatban nem a szakmai felkészítő táborok módszertanáról lesz szó, inkább azokról a müvészeti táborokról, melyekben szabadidős tevékenységre is van idő

\section{Mit jelent számomra a táborozás?}

A tábori pedagógiai tevékenység egyik fontos eleme a keretrendszer, melyeket a tábor ideje alatt új vagy az előző táborok hagyományaként egyhetes életünkben betartunk, a másik fontos összetevőt pedig azok a játékok jelenthetik, melyekkel ezt a keretrendszert feltöltjük és kialakítjuk. Az iskola is lehet olyan terep, ahol saját hagyományok és belső szabályok kialakításával, valamint szabályok és játékok bevezetésével a külső kényszerből belső szabálytudat lesz, és örömforrás. Mert játszani jó, nemcsak a táborban, hanem az iskolában is. Csak reménykedni tudok, hogy vagyunk még elegen, akik ezeket a játékokat felnőttként megőrizzük, és át tudjuk adni a következő generációknak.

Táborozni annyi, mint

- játékban, játékkal pedagógiai impulzusokat adni és kapni,

- kipróbálni magam új helyzetekben,

- együtt lenni olyanokkal, akikkel csak hetente egyszer vagy még annyiszor sem találkozunk,

- kilépni a hétköznapok valóságából, és létrehozni egy közös új valóságot, melynek az ideje véges,

- rövid idő alatt közösséget hozni létre, majd formálni, és eljuttatni a közös alkotás élményéig.

Ezek után következzék a táborozáshoz köthető komplex játékok felsorolása. A játékokat ezúttal ábécérendben közlöm, célom ezzel annak hangsúlyozása, hogy a gyüjteményben szereplö leírások kiegészíthetők további variánsokkal, valamint nyitott az út a további kiegészítések előtt. 


\section{Tábori nagy játékok}

Az elnevezést az indokolja, hogy többségükben ezek több kisebb feladatot magukban foglaló, komplex játékok; egész napos, félnapos programok, nagy létszámmal, világos, áttekinthető szabályokkal. Akadnak köztük, melyek a tábor egész ideje alatt játszhatók, s természetesen mindegyikük szabadon alakítható a tábor adottságai, a gyerekek képességei és a pedagógusok vállalkozó kedve alapján. A kisebb, nemcsak tábori, hanem iskolai, színjátszós vagy szabadidős játékokról a felhasznált irodalomban ajánlok forrásokat (Gabnai, I993, 2005; Kaposi, I993, 2013; Elöd, 2004; Esztergályos, 1990; Karlóczai, I987, 20I5). Az így összegyűjtött játékokat ábécérendben sorolom fel, egyes esetekben azt is feltüntetve, hol lehet még utánuk olvasni, illetve az egymásra épülő játékoknál megjelöltem a kapcsolódási pontokat. Remélem, haszonnal forgatja majd felnőtt és gyermek egyaránt, és ki fogja egészíteni saját játékaival a gyüjteményt.

Alternatíva - extra tevékenységek - felajánlása

Mindenki tud valamit a felnőttek közül, ami különleges, és egyáltalán nem kötődik a tábor tematikájához - van, aki az autószereléssel kapcsolatos ismereteibe avat be, akad, aki fényképezni tanítja a gyerekeket, más hangszeres tudását osztja meg, rajzolni tanít, logikai feladványokat megoldani, a lényeg az, hogy nagyjából hasonló időtartamú foglalkozások legyenek a délutáni programban. Érdemes előzetesen feliratkozni a tevékenységekre, így nem közben kell kitalálni a gyerekeknek a menetrendet.

Árverés / Pontbeváltás

A tulajdonságárverés mintájára a tábor végén az összegyüjtött tábori pénzt együtt, csapatban vagy külön, egyénenként fel lehet használni különbözö, a felnőttek által felajánlott szolgáltatásokra vagy tábori ajándékra. Néhány ötlet (a tábor szervezőinek kreativitására van bízva a folytatás): jósda, egyéni ágyazás, külön kiszolgálás az ebédlőben, arcfestés, három kívánság, szerenád, rabszolgavásár stb. Fontos, hogy a végén ezeket a pénzeket elköltsék, s ennek egyik legjobb módja az árverés. Szerenád az ablak alatt - ki ad többet érte?

\section{Bátorságpróba}

Általános rémisztgető próbatétel a szervezők kreativitásának megfelelően fogvacogtató vagy végigröhögős változatban. Vannak olyan játékok, melyeket lehet jól és lehet kevésbé jól játszani. Én azt a fajta bátorságpróbát, hogy feküdjünk a füben, és fogjuk meg az arra haladók lábát stb. alapvetően nem tartom kreatív játéknak. Saját tapasztalatom alapján csak a felnőttek ijednek meg az ilyen bátorságpróbától, a gyerekek - a kábeltévék és térhatású mozifilmek után - legfeljebb csak nevetésükkel jutalmazzák igyekezetünket, hogy valami rémisztő meglepetésben részesítsük őket. Közben a felnőttek igyekeznek a tényleg félős kisebbeket pátyolgatni, míg a nagyobbak - félelemből vagy rátartiságból - megpróbálják bagatellizálni a feladatokat, $\mathrm{s}$ közben mindenki ordít. A másik probléma, hogy a szervezőknek ki kell találniuk, hogy akik már végeztek vagy még nem kerültek sorra, mivel múlassák az időt a sötétben.

Néhány ötlet a bátorságpróbához:

I. Horror Sarok - zárt sötét vagy félsötét térben, önkéntes részvétellel egy-két elszánt felnőtt szerepben, intenzív munkával próbára teszi a résztvevőket, akik párban, vagy egyénileg vállalják a próbát, közben alternatív tábori program a többieknek.

2. A Láthatatlan kiállítás mintájára a próbatétel valóban teljes sötétségben zajlik, és így kell teljesíteni.

3. Lásd a gyüjtemény többi éjszakai feladatát (éjszakai akadályverseny, éjszakai túra, éjszakai állat játék). 
Címek, rangok (Szakall, 20I2)

A jutalmazás egyik formája lehet a címadás, vagyis valamilyen tábori kitüntetés adományozása. Ez lehet valamilyen tábori $L E G$ is, de még jobb, ha a kimagasló munkát végzőket, a többiek, vagy a felnőttek javaslata alapján tábori címben részestjük a végén - a Bánvölgyi Bán vagy Prefektus rang, vagy bármi más cím, amit nem kaphat meg akárki. Egy ilyen jutalom akár évekre megtarthat valakit a tábori közösségben.

Éjszakai akadályverseny

Ügyességi, logikai, érzékszervi feladatok megoldása a tábor területén belül vagy jól ismert és biztonságos külső helyszínen. Az állomások megtalálása ugyanúgy feladatot jelent a sötétben. Egy zseblámpával játsszuk, vagy éppen zseblámpa nélkül...

Éjszakai állat játék (Szakall, 20I2)

Egy-egy állomás felkeresése a feladat adott sorrendben. Ez is a forgószínpad elvére épül. A játékban ahány csapat van, annyi állomást kell felkeresniük a csapatoknak. Az állomáson helyezkednek az állathangot kiadó felnőttek. A sorrend adott (tehát kecske-lómajom-kakas stb.), csak mindenkinek más lesz az első, így a menetlevelén máshol kezdi az állatok aláírásának begyüjtését. A tábor területén belül bárhol lehet az állomás - mivel éjszakai játék, ezért érdemes kikötni, hogy mi az a terület, melyen belül folyhat a keresgélés. Az állomást úgy lehet megtalálni, hogy az állomáson lévő felnőtt/ifi az adott állat hangját adja ki. Ezt lehet más keretjátékban mindenféle más fantáziaállattal is játszani - a toalettkacsától a mandragóragyökér hangjáig. A Fantázia táborban hangszerekkel jeleztük az állatokat.

Éjszakai túra

Mindenféle feladat, éjszakai játék ellenére nekem a legnagyobb élményt ebben az évben az éjszakai túra jelentette a Mátrában, ahol a tábor két csoportban, szakavatott vezető segítségével tett egy túrát. Közben megnéztünk egy barlangot, figyeltünk erdö-mező hangjaira, elmentünk a föúton egy kis erdei útig, ahol mindenkinek lehetöleg egyesével kellett eljutni a fény felé egy ösvényen, ahol már várt minket a táborvezető. Sikerült elcsendesednünk, és az éjszakai túra tényleg az erdőröl és a „zajos” csendröl szólt.

Faliújság (Szakall, 20I2)

A faliújságnak különösen fontos szerepe lehet a táborban - elsősorban a tájékoztatás miatt. Fontos információk kerülhetnek fel, úgymint a napirend, a tábori ének szövege, a pontszerző csapatversenyek állása, valamint a következő napi program. Halkan említjük az olvasás gyakorlásában betöltött szerepét is.

Falujáték

A játék lényege, hogy amikor már egymást jól ismerik a gyerekek, olyan feladatsort állítunk nekik össze, amit a helyi, a bennünket befogadó közösségben kell teljesíteniük. Meg kell keresniük a legidősebb embert, vagy kell szerezni egy tojást, és minél több emberrel alá kell íratni. A helyi jellegzetességekből és vállalkozó szellemü helyi erőkből kiindulva mindenféle feladatot ki lehet találni. Néhány jó tanács a szervezéshez:

I. Vigyázni kell, hogy a játékban ne legyen lenéző vagy a helyieket (esetleg a gyerekeket) kellemetlen helyzetbe hozó feladat. Nem biztos, hogy a legextrémebb feladat a legcélravezetőbb, hiszen célunk az, hogy ismerkedjünk meg a helyi szokásokkal, hagyományokkal, élettel és emberekkel.

2. Forgalmas helyeken inkább legyen felnőtt kísérö minden csapattal, aki a feladatok megoldásában nem, de a tájékozódásban és a közlekedésben segíti a gyerekeket. 
3. A jó falujáték nem sablonok alapján terveződik, hanem gondos előkészítést igényel, hogy megtaláljuk a helyi erőket, ezért is érdemes a táborozás második felére vagy éppen zárásnak tervezni.

Falusi olimpia

Olyan, mint a tábori olimpia, csak népi játékokkal - ez lehet eszközös (bigézés, csülközés, métázás) és eszköz nélküli játék is (fogójátékok, énekes népi játékok). A végén mulatság, akár táncház zárhatja a versenyt. A csapatok faluneveket, mesterségneveket választhatnak maguknak. Ez a szervezőket további játékok beépítésére sarkallhatja.

Fele-sem-igaz

Ebben a vetélkedőformában kérdéseket kap három csapat, majd három felnőtt igyekszik ezekre észszerü válaszokat adni. Minden csapat választ egy válaszadót, majd vagy hisz neki, vagy sem. Mindhárom válasz hihető, de csak egy az igaz. Pont jár a hamis és az igaz válasz felismeréséért.

\section{Forgatag}

Játékok, feladatok, kézmüves asztalok egy téma köré csoportosítva. Bárhol be lehet kapcsolódni, egy feladatot többször ki lehet próbálni, a végén díjazni lehet a legtöbb pontot összegyüjtőket. Kell hozzá pontgyüjtő kártya (régen menetlevélnek hívták), lehetőleg többféle nehézségü feladat, hogy mindenkinek legyen sikerélménye. A legjobb, ha kisebb csapatokat alakítunk, s együtt vesznek részt a feladatok megoldásában. Jól lehet használni nagytábori vetélkedőnél, családi délutánon, közösségi rendezvényeken, ahol nem megoldható a zárt csapatszervezés.

\section{Forgószínpad}

Ez nem egy külön játék, hanem egy jól müködő rendszer. Régen az akadályjátékok az első állomástól indultak, és az utolsónál értek véget, majd vártunk az elején az indulásra és a végén arra, hogy az utolsó csapat is beérkezzen. A forgószínpad formában mindenki egyszerre indul, egyszerre vált és egyszerre fejezi be a játékot. Ehhez fontos, hogy mindenhol azonos idejü feladat legyen, és az is lényeges, hogy annyi állomás legyen, mint ahány csapat. A játékban részt vevők egy területet járnak be. Ebben a rendszerben a feladatok nem épülhetnek egymásra.

Gyilkos a táborban

A klasszikus gyilkosos játék (Kaposi, 1993) tábori változatában a nap elején a játékgazda által kijelölt gyilkos, ha kettesben marad áldozatával, akkor megmutatja neki gyilkos-igazolványát, és felköti rá a szalagot. A gyilkosnak lehet jelvénye is. Fontos, hogy pontosan meghatározzuk a játék kereteit - pl. a foglalkozásokon nem lehet gyilkolászni. Lásd még kupakos gyilkosnál.

\section{Kaszinó}

A szerencsejátékok tábori változata - lehetőleg minél több játék -, malomtól a pókerig, félkarú automatától a huszonegyig. A játékhoz szükséges zsetont vagy már korábbi játékokban megszerzett tábori pénzükböl váltják be (pompás hely lehet a tábori pénz elköltésére is), vagy egyformán kap mindenki a játék elején. Érdemes hozzá kapcsolni egy alkalmi büfét, limonádézót, ahol a nyereséget azonnal el lehet költeni, vagy a játék végén visszaváltható minden tábori valutára. 
Ki mit tud? (Most mutasd meg magad!)

Ez a forma nemcsak a televízióban vagy az iskolában lehet jó játék, hanem a táborban is. Általában a művészeti táborokban akad hangszer, eszköz mindenféle képesség bemutatására: akad, aki tornázik, aki verset mond, nagyon jó alkalom ez arra, hogy az egy szobában lakók összefogjanak, és közösen lépjenek fel valamivel. Ez tulajdonképpen a tábortüzi müsor volt régen, ahol nem elsősorban a müvészi érték, hanem a szórakozás és a nevetés a cél. Jó alkalom ez arra, hogy a felnőttek is megmutatkozzanak, ezzel is bátorítva a gyerekeket a fellépésre, és megmutatván egy másik oldalukat is.

\section{Kirándulás}

Nemcsak az éjszakai kirándulás jó, hanem természetesen a nappali is. Az erdei kirándulás gazdag szakirodalommal rendelkezik, ezért erre nem fogok külön kitérni. A városi gyerekeknek igazából meg kell tanítanunk azt is, hogy mire kell figyelniük út közben. Nagyon jó, ha ehhez hívunk szakembert, vagy felkészülünk alaposan a környékből. A kirándulás egyben próbatétel is lehet. Tudunk-e egymás helyett a természetre, s ezzel együtt önmagunkra figyelni. A másik próbatétel a megtett kilométerekhez kapcsolódik, figyeljünk arra, hogy ki megy elöl, s ki marad a végén a lemaradókkal. Csak egy jó tanács a végén: ha összevártuk egymást, akkor hagyjunk egy kis pihenőidőt az utoljára beérkezetteknek is. További hasznos ismeretekre lehet szert tenni a vándortáborozás és a túrázás vonatkozó szakirodalmában (Bánhidi és mtsai, 2004; Bodnár, 1989).

\section{Közös főzés}

Nincs jobb a szabad tüzön fözésnél, de természetesen egy felszerelt konyha is megteszi. Jobban esik a falat, ha a paprikás krumplihoz nemcsak a tüzet raktuk mi, hanem a krumplit és a kolbászt is saját magunk aprítottuk bele. Hétköznapi tevékenység, mégis hihetetlen jó tábori esemény lehet belőle, ha a felnőttek nem akarnak mindent készen a gyerekek elé tenni, hiszen erröl szól az ügyeletes csapat intézménye is. Nem feltétlenül kell versenyt csinálni belőle, itt a motivációt a korgó gyomor jelenti.

Kupakos gyilkos

Ebben a változatban a gyilkos a táborban egy diszkrét helyen megmutatja a gyilkos jelvényét (ez mondjuk lehet egy kupak), és átadja a tisztséget annak, akit megölt. Magát megjelöli (kereszt a csuklón, homlokon vagy karkötő segítségével), és folyatódik a játék egészen addig, míg mindenki be nem kapcsolódik.

\section{Lakoma}

A közös evés nem csak a napirend szerinti étkezések rendjét, rítusát jelentheti. Készülhetünk egy alkalommal saját lakomával is, mely egy közös fözés eredménye is lehet, de néha elég egy gyümölccsel telerakott asztal is. Terített asztalunk mellé zenét, tósztot, ünnepséget is keríthetünk. Az a tapasztalat, hogy a gyerekek a közös lakomázás alkalmával sokszor kipróbálnak olyan zöldséget, egyebet is, melyre sem az iskola, sem szüleik, de még a nagymama sem tudta addig rávenni őket. Bármennyire közhelyesen hangzik, de a legegyszerübb dolog is újdonságként érheti a gyerekeket - például hogy egyszerre kezdjük az étkezést, és mindenkit megvárunk az asztalbontással.

Lefekvés elötti programok

Mese- vagy történetmondás, éneklés, az esti rutin ellenőrzése. Esetleges konfliktusok, helyzetek megbeszélésére is kiválóan alkalmas idő, hogy ne feküdjünk le megbeszélés nélkül. Miután a tábor vezetőségének ezek után jön a saját egyeztető megbeszélése (álta- 
lában), ezért jó, ha erre van külön szobafelelős, még jobb, ha ifi, pláne, ha egy-egy szobához ketten mennek - több lépcsőben. Minél kisebbekből áll a tábor, annál fontosabb a lámpaoltás és a pihenés - mert ettől nagyon nyügös lehet másnap gyermek és felnőtt egyaránt.

Legek táblája

A faliújságra hirdethetünk és gyüjthetünk LEG-eket. Mindenki valamiben különbözik a többiektől - a legszebb hangú, a legnagyobb lábú, a legtöbbet tüsszentő stb. Érdemes öszszegyüjteni, keresni, hogy a tábor végére mindenki legyen valamiben a leg...

Méta (Szakall, 20I2)

A leírás bármelyik játékkönyvben megtalálható. Ez a játék lehet a falusi olimpia befejező eleme, vagy általános, minden délutáni szabadidős játék is. Labda és bot használata miatt a Varázslótáborban ez volt a kviddics.

Mobil a táborban

Jó, ez nem játék, de lehet játékot csinálni belőle, vagyis szabályt, amit betart mindenki, pedagógus, szülő és gyerek egyaránt. Ez a problémakör még kimaradt a 2007-es gyüjtésből - érthető okok miatt, ám tíz év elteltével igenis foglalkoznunk kell vele. Minden tábori levélben érdemes tisztázni a táborba hozott értékek problémáját és azok használatának szabályait. A különböző kommunikációs eszközök úgyis bekerülnek a táborba, ahogy kikoptak a nyilvános telefonkészülékek, erre szükség is van. De szabályok nélkül a foglalkozás közepén mindig megszólal a telefon, hiszen a szülő érdeklődik a gyermek hogyléte és a reggeli minősége felől. A Fantázia táborban erre az volt a szabály, hogy a gyerekek a tábor elején leadták a telefont a csoportvezetőnek, majd minden este egy megadott időpontban (vacsora után) kapták vissza - egy órára. Remekül müködött, mindenki egyszerre foglalkozott az otthon maradt kapcsolataival, és nem a foglalkozások idejét, pláne nem az éjszakát használta ugyanerre. Így a szülő is tudta, hogy mikor keresheti a gyermeket, és a gyermek sem érezte azt, hogy állandóan informálnia kell az otthon maradottakat. Remek visszajelzés volt, amikor egy táborozó megjegyezte, hogy már nem is hiányzik neki a telefon állandó közelsége.

Mocsárjáró akadályjáték

Egy Io $\times$ Io méteres nagy pálya van felrajzolva a betonra, berácsozva, ezen léphetnek a csapatok, akik körbeülik a pályát. A csapatokat képviselö bábukkal lóugrásban lehet lépni. Egy-egy kiemelt mező feladatot rejt, ezekhez eljutva a csapatok kérdést kapnak, vagy feladatot oldanak meg pontokért. Stratégiai játék és csapatjáték egyszerre.

Nyomozós játék

Három csapatban játsszuk, vagy éppen az aktuális kiscsoportos szerkezetben. Lényege, hogy kiül 8-I2 felnőtt, és mindegyik elkezd egy saját történetet mesélni. De a történetek közül csak egy felel meg a valóságnak, a többi kitalált. Az első mondatok meghallgatása után a csoportok kérdést tehetnek fel a „történetmondóknak”, majd szavazással, melyben mindegyik csoportnak egy szavazata van, eldöntik, hogy ki nem mond szerintük igazat, kinek hamis a története. Akit kiszavaztak, az kiesik a játékból, de a többiek folytatják tovább a mesélést az újabb fordulóban, melyet újabb kérdések és újabb kiszavazás követ. Nagyon fontos, hogy csak egy igazi történet van, akár kiesik az a szavazáson, akár nem. A végén persze minden kiderül. 


\section{Pályázatok}

A táboron belül általában a szabadidőhöz lehet meghirdetni mindenféle pályázatot, a versírástól a logikai fejtörőkig. A gyerekek szeretnek egyénileg is pályázni, sőt megmutatni magukat a többiek előtt. Ảm aki nem mer a Ki mit tud?-ra jelentkezni, elindulhat valami írásos feladatban is. Saját ötletű pályázatom a „Sten Malte Költői Verseny” volt.

Reggeli ébresztés és torna

Az ébresztés sarkalatos pontja a tábor életének - ilyenkor derül ki, hogy ki volt végig ébren, ki az, aki a táborozás adta szabadságban éjszakai ébrenléttel teszi próbára magát és szobatársait. Az intenzív táborozás, a jó levegő egyébként is fárasztó, így néhány nap alatt kialakul a rend, amiben az éjszaka (vagy inkább az éjszaka java része) mégiscsak alvásra és nem beszélgetésre, rendetlenkedésre használtatik. Ellenkező esetben nem tudunk másnap részt venni a programon, zombiként megyünk reggelizni, konfliktusba keveredünk egymással, a pedagógusokkal. A tábori élet fontos része a felnőttek pihenése is, mármint, hogy a szakmai munkával foglalkozók is tudjanak egy kicsit pihenni. A munkamegosztásban juthat szerep a reggeli ébresztőknek, és a reggeli tornát vezető pedagógusnak/ifinek is. Ez ismét lehet tábori pénzszerző tevékenység. A Fantázia táborban az, aki mind a hét reggelt végigtornázta, kiérdemelte a Hétpróbás címet a záráskor.

Reggeli közös játék

Kell, hogy a nap mindenki számára elkezdődjön, ennek legjobb formája a bemelegítő közös játék. A kiscsoportos foglalkozások elött összegyülnek a szakrális téren. A gyülekezőn a teljes tábor egy közösségként vesz részt. Ez a rész alkalmas arra, hogy a közös játék mellett a táborvezetés elmondja a nap programját, az esti program eredményét, az éjszaka tanulságait és minden további praktikus és fontos információt.

\section{Rókavadászat}

A tábor területén elrejtünk jó sok rókajelet, például egy kis papírt, melyre rókát rajzoltunk, vagy hajtogattunk, vágtunk. A cél, hogy adott idő alatt egyénenként vagy csapatban minél többet összegyüjtsenek a gyerekek.

\section{Sportok}

A különböző sportolási lehetőségek számbavétele után minden ágban szervezhető bajnokság. Egyéni és kiscsoportos focitól egészen a tábori olimpiáig széles a mozgásos játékok tára. Lásd még számháború, tábori olimpia, a klasszikus sportágak (foci, kosár...) mellett bármelyik tábori változata - pl. úszóverseny a vizes füvön, kötélhúzás kötél nélkül egymásba kapaszkodva, mocsárjárás egyszerre, egyéb sorversenyek, de idetartozik a vízi csata és a méta is.

\section{Számháború (Szakall, 20I2)}

Két csapat: kékek és pirosak, négyjegyü számmal a fejükön. Az egyik a zászló megszerzéséért küzd, a másik védi a zászlót, melyet látható helyen, a föld fölött kell elhelyezniük. Nem lehet földet imádni (leszorítani a fejet a földre), eget imádni (feltartani a fejet az égre), nem lehet a számot kézzel vagy bármi más eszközzel eltakarni. Kézitusának sincs helye. Akit leolvasnak, annak le kell vennie a számát, és el kell hagynia a játékteret szó nélkül. A játék szerepcserével megismételendő! Lehet tankolni, összekapaszkodni és úgy megközelíteni a zászlóhelyet. 
Színjátékos vetélkedő (Szakall, 20I2)

Ebben az esti programban különböző szerepjátékos feladatok várnak a csapatokra. Ilyenek a paródia, a most mutasd meg játék, jelenetkészítés, gépkészítés, közös éneklés, páros versmondás stb. A játék során külön örömforrás lehet a „zsüri” produkciója vagy mókás értékelése.

Szakrális tér / gyülekezőhely (Józsa és Tegyi, 20II)

A tábor időben és térben is saját szabályokkal rendelkezik, ezért fontos meghatároznunk, közösen megegyeznünk a gyülekezés szabályaiban is. Amennyiben ez adott (pl. az épületek/sátrak által körülvett) tér, akkor is igyekezzünk egyénivé, sőt napról napra díszesebbé tenni. Egy csokor, egy napóra, egy előző napi játék maradék jelzései, vagy, ahogy a Fantázia táborban szokás: egy totemoszlop, amelyre mindennap felkerül az előző nap legfontosabb élményét jelképező jelvény.

Tábori himnusz

„Mert kell egy hely...”, ahogy a dal mondja, de a hely (szakrális tér) mellett kell egy dal is. Összetartó, közösségépítő dal, amit közösen tudunk énekelni. Felkerülhet a faliújságra is a szövege. A tábor elején talán még papírról olvasva a szövegét, a végén pedig együtt bőgve minden versszakán. Lehet olyan dal, ami egy az egyben átvehető, énekelhető, s természetesen lehet írni egy könnyen énekelhető dallamra saját, tábori tematikájú szöveget.

Tábori napló - képben, rajzban, jelvényben

Fontos a tábori idő rendszerbe foglalása, ehhez két tábori formát tudok ajánlani, az egyik a tábori napló, melynek bejegyzéseit ki lehet függeszteni a faliújságra, majd készülhet belőle egy nagy könyv is. Készülhet az azték naptárak mintájára, egy nagy papírra, a tábor indulása a felrajzolt csigaház belső része, s az egyes tábori történéseket vonallal elválasztva egy-egy rekeszbe rajzolják az ezt vállalók. Emlékeztetők ezek, ikonikus ábrázolások, melyek a legfontosabb pillanatokat rögzítik (pl. amikor megijesztett minket a medve, amikor strandolni voltunk Egerben, stb.). Ahogy telik az idő, úgy jutunk egyre kijjebb a csigavonalon, s lesz egyre több emlékünk. A Fantázia táborban az első napon totemoszlopot állítanak, melyre mindennap az ügyeletes csoport felfesti a nap számukra legfontosabb eseményéről az emlékező jelvényt, mely egy lefürészelt ág szeletre. Így lesz egyre több jelvény a fán, ahogy múlik a tábori idő, napra nap.

Tábori olimpia (Szakall, 20I2)

Egész napos program lehet, de akár egy tábort is fel lehet építeni rá. Mozgásos és szellemi vetélkedők a csapatok között. Lehet országnevet választani, megnyitni látványosan az olimpiát, különböző klasszikus és tábori sportokban összemérni az erőnket, és a végén ismét úgy zárni, hogy igazi olimpiai hangulat legyen.

Tábori pénz (Szakall, 20I2)

Fabatka, gyöngy, tallér, mindenféle apróság, amit vagy valóságos pénzként kézbe adunk, vagy egy bankkártyára matricákat ragasztunk, vagy egy számítógépen vagy kartonon nyilvántartott virtuális pénzként tartjuk nyilván. Lehet kapni tábori pénzt a játékokban való részvételért, a nyerésért, feladatmegoldásért, takarításért, tulajdonképpen bármiért, amit a tábor vezetői jutalmazásra méltónak találnak. Értékközpontú világunkban éppolyan dolgokat lehet jutalmazni tábori pénzzel, ami nem biztos, hogy a külvilág számára is ugyanolyan értékes. S hogy mi legyen az igazi pénzzel? Szakall Judit táboraiban meg lehetett bízni egy-egy felnőttet, hogy segítsen a kicsiknél a pénzbeosztásban. Vagy ha nagyon szerencsések vagyunk, akkor nincs pénzköltő hely a közelben... 


\section{Tábori postafiók / levelezés}

A faliújság mellett az egymás közti írásos kommunikáció feladatát látja el a tábori postafiók. Mindenkinek saját postafiókja van, egy táblára ragasztott névvel, egyéni díszítéssel ellátott boríték, ide lehet egymásnak üzenetet küldeni. Például a titkos testvérek üzenhetnek a másiknak névtelenül, kedvességeket vagy éppen titkos üzenetet, bocsánatkérést is lehet küldeni a másiknak. A postafiókok állandóan üzemelnek, de volt már rá példa, hogy éjféltől reggel ötig, valamint a foglalkozások idejére korlátoznunk kellett a postafiók ellenőrzését, mert akadt, aki éjjel kettőkor gondolta, hogy most kell feltétlenül ellenőriznie a postafiókját, hátha kapott valamit.

Tábori újság/ híradó játék

A tábor során összegyüjtött produkciók, versek, írások, a feladatmegoldások közben született munkák összeszerkesztése egy újságba: külön gyerekszerkesztőséggel. Születhet egyszerüen a faliújságra is, még jobb, ha ki tudjuk nyomtatni, és a tábor végén mindenki kezébe tudjuk adni. Ha már a technika került szóba, érdemes elgondolkodni a tábori híradón is, hiszen ennek szerkesztéséhez ma már elég egy mobiltelefon vagy egy fényképezőgép és egy laptop. A gyerekek érdeklődéssel nézik a napi összefoglalót rövid hírmüsor keretében, s minden megmaradt írás, elkészült felvétel hasznos lehet a tábori találkozóknál, visszaemlékezéseknél, pályázati beszámolónál.

\section{Tábortüz}

Felnőtt felügyelettel fontos tanulási terület lehet a fa összegyüjtése, a tüzrakás módja és lehetőségei, a tüz fenntartásának és eloltásának megtanulása. Ebben is érdemes elővenni a cserkész- vagy az úttörőkönyveket. A favágás szerszámai és azok biztonságos használatának megtanulása biztosan le fog kötni néhány vállalkozó szellemű fiút és lányt. A tábortüz szakrális tér lehet, emellett tábori bemutatókat, Ki mit tud?-ot lehet tartani, énekelhetünk, meghívott vendéget lehet ültetni köré. A virrasztásnál pedig nincs jobb hely, mint a hamvadó parázs.

Tematikus akadályverseny (Bodnár, I989; Szakall, 20I2)

Tábori keretjátékokra, akadályverseny tematikára rengeteg példát lehet találni a cserkészek kézikönyveiben és elektronikus felületein. A klasszikus szerkezet: adott pályán Io percenként indulnak a csapatok, a végén összegyülnek, és eredményt hirdetünk. Előnye, hogy azonos feladatokat oldanak meg az állomásokon, értékeljük a kreativitást, a csapat tagjainak ismereteit az adott témában. Együttmüködésüket, menetlevelüket külön díjazni lehet. Valahonnan valahová jutnak el, ezért alkalmas egy távolság megtételére is (pl. kiránduláson).

Hátránya, hogy időben bizony el tud csúszni, s mire az utolsó csapat is beér, addigra az elsők már végképp kiestek a játékból, és csak a játék végét várják.

\section{Titkos testvér / Angyali üzenet / Angyalkázás}

Egyezzünk meg, hogy a játékban a tábor idején mindenkinek lesz egy titkos testvére. Aki üzenetet írhat neki, aki vigyáz, odafigyel rá. Legjobb, ha a játékgazda sorba veszi a gyerekeket, és beosztja, hogy kinek ki lesz a titkos testvére láncban. Egy szabadon álló falra mindenkinek felragasztjuk a borítékját, mint a postaládát, mint egy üzenőfalat. Ebbe várja titkos testvére üzeneteit, de nemcsak tőle kaphat üzenetet, ajándékot, hanem bárki mástól is. A játék osztálytermi helyzetben is életképes. Fontos, hogy ne derüljön ki, hogy ki kinek a titkos testvére - nem is ez a játék célja. A sorrendet természetesen egy ember tudja, ő lesz a titokgazda, s vitás helyzetek, félreértések esetén hozzá kell fordulni. A tábor végén érdemes feloldani a titkokat. Szerencsére ennél a játéknál a sorsszerü kapcsolatterem- 
tés ellenére negatív tapasztalatunk nem volt. Sok múlik természetesen a játék felvezetésén, hogy annak ellenére, hogy ez egy játék, ezt csak kellő komolysággal lehet játszani. Néha azt is el kell fogadnunk, ha a saját titkos testvérünk kevésbé aktív.

\section{Torpedó}

A klasszikus páros játék csapatváltozata. Mindenkinek van egy négyzethálós táblája, mindenki lőhet mindenkire. Egy-egy fordulóban Io lövés lehetséges a játék gyorsítása érdekében. Kell egy felnőtt vezérkar, amely jelzi és nyilvántartja a találatokat. Időnként érdemes megszakítani a lövöldözést egy kis mozgásos játékkal. Az nyer, akinek a végén marad még hajója.

\section{Ügyeletes csapat}

Nemcsak a konyhások, karbantartók és a következő turnus táborozói miatt fontos egyes tábori munkafolyamatokkal felelösként megbízni a csoportokat, hanem azért is, mert sok gyermek itt találkozik elöször a beágyazás, a terítés vagy éppen a sepregetés feladatával. Itt csapatban végezve, együtt tanulják egymás segítését, saját környezetünk rendben tartását és egymás munkájának értékelését is - például a házak közötti tisztasági versenyben.

Virrasztás - éjszakai feladatokkal

Nem olyan nagy baj, ha egy összeszokott táborban az utolsó éjszaka önkéntes virrasztást hirdetünk. Fontos azonban, hogy legyen felnőtt is a fennmaradók között. Nem feltétlenül azért, hogy állandóan a gyerekek sarkában legyen, sokkal inkább azért, hogy tudják, kihez kell fordulni, és az illető hol van, ha történetesen szükség lenne rá. A virrasztás elején készülhetünk külön játékokkal is, feladatokkal, társasjátékkal, külön vacsorával, táborkerüléssel.

Vízi csata (paint ball - táborban) (Szakall, 20I2)

Szükséges két csapat, két különböző színủ mosható festékkel töltött edény, valamint gyógyszertárban beszerezhető mủanyag fecskendők a játszók létszámának megfelelően. Kellenek bírók és koordinátorok, valamint egy gyülekezőhely, ahol a kiesettek megvitathatják az eseményeket.

A feladat: Az ellenfél bázisának elfoglalása vagy az ellenfél megsemmisítése. A két festékvödörhöz (bázishoz) kell visszatérni a csapat tagjainak újratöltés céljából.

Egy fehér pólóra rajzolt kör jelentette az életet, ha ezen belül megjelent az ellenfél színes foltja, akkor az illető kiesett. Vigyázat, a festékes földön kúszva is ki lehet esni a játékból. Olcsóbb változatában fürdőruhában is tudjuk játszani, az élet köre kis négyzetes lepedödarabra van rajzolva, amit nyakba akasztunk.

\section{Összefoglaló helyett}

A legfrissebb nyári élményemmel kezdem. Egy délután épp a házak felé indulok a parádi táborban, mikor szembejön két táborozó lány. Egymásra nézünk, de valahogy a köszönés elmarad. Nem is egy csoportban vagyunk, még csak két napja tart a tábor, ki tudja, kinek hogyan lehet köszönni. Megállunk. Értik, érzik a helyzetet, hüha, itt elmaradt a köszönés, ezért aztán jó hangosan köszönnek, mint az iskolában. Megállunk. Felhívom a figyelmüket arra, hogy ilyen hihetetlenül udvarias és pontos köszönést csak azok tesznek a táborban, akik valami rosszban sántikálnak. Összenevetünk. Akkor hogyan köszönjünk, hogy ne legyen feltünő? - kérdezik. Ahogy mindenki más a táborban - válaszolom. Elmegyünk egymás mellett, és morgunk valamit az orrunk alatt. Hrrr-krrr... egyszóval semmi érthetőt. Tényleg? Tényleg. Ezt akkor most próbáljuk el! Már tíz perc is eltelt, s mi még min- 
dig az észrevétlen köszönés problémáját boncolgatjuk. Nevetve búcsúzunk, mindenki megy a dolgára. A legközelebbi találkozásnál először harsányan köszönnek, majd amikor elmegyünk egymás mellett, megkapom a morgásos köszönést is - végig a tábor ideje alatt.

Ebben a játékos helyzetben egyszerre volt szó a kiskamaszok köszönési nehézségeiről, a pedagógus szerepéről a táborban, gyerek- és felnőttszerepekről és az együttmüködésről. A végül kialakult játék nem csak arról szólt, hogy miként kell feltünés nélkül viselkednünk a táborban. Felnőtt és gyerek pedagógiai játéka - közben összenevettünk és megtanultuk, hogy egy kiskamaszt is be lehet vonni a játékba, és egy felnőtt is lehet játszótárs a legegyszerübb helyzetekben is. Így lehetnek ezek a játékok is egyszerre jó mókák és pedagógiai, nevelési helyzetek.

Végezetül egy régi élmény: ülünk valahol a Bükk aljában, egy vándortábor utolsó állomásán, beszélgetünk, egy gimnazista (én) és a körülöttem lévő felső tagozatos kiskamaszok. Tanár szeretnék lenni én is, mondja az egyikük nevetve, de mondatán így is megütközöm. Miattad, mondja szemlesütve, mert tök jó volt itt a táborban veletek. No comment...

\section{Irodalomjegyzék}

Bábosik István (2004): Neveléselmélet. Osiris, Budapest.

Bánhidi Attila, Csóka Géza, Détárné Bikfalvi Mónika, Mályi József és Mészáros János (2004): Vándortáborozási kézikönyv. Mobilitás, Budapest.

Bodnár Gábor (I989): Cserkészkönyv I-III. Püski Kiadó, Budapest.

Comenius (I999): Játszó iskola. In Ködöböcz József (szerk.): Comenius és a magyar iskola. Bibliotheca Comeniana, VII. Sárospatak. 73-I09.

Előd Nóra (2003, szerk.): Add tovább! Candy Kiadó, Veszprém.

Esztergályos Jenő (I990): Ezer játék. Magánkiadás, Celldömölk.

Farkas Endre (1992, szerk.): Nyugodtan tegezz! Leveleki Eszter pedagógiájáról. Grafo-press, Budapest.

Gabnai Katalin (1993): Drámajátékok: gyermekeknek, fiataloknak, felnötteknek. Marczibányi Téri Müvelödési Központ, Budapest.

Gabnai Katalin (2005): Drámajátékok: bevezetés a drámapedagógiába. Helikon, Budapest.

Józsa Katalin és Tegyi Tibor (20II): Fantázia drámajátszó táborok Parádfürdőn. Napló-társnapló. Kecskeméti Ifjúsági Otthon, Kecskemét.

Kaposi László (I993, szerk.): Játékkönyv. Kerekasztal Színházi Nevelési Központ, Marczibányi Téri Müvelődési Központ, Budapest.

Kaposi László (20I3, szerk.): Játékkönyv. Marczibányi Téri Müvelődési Központ, Budapest.
Karlóczai Mariann (2015): Komámasszony, hol az olló? Flaccus, Budapest.

Körömi Gábor (2007): Tematikus vetélkedők, tábori játékok - közös ötletelés. Drámapedagógiai Magazin, I7. 2. sz. 23-37.

Körömi Gábor (20I3): Volt egy tábor Lengyelben.. Drámapedagógiai Magazin, 23. 2. sz. I2-I8.

Szakall Judit (20I2, szerk.): Táborozás - Hasznos tudnivalók táborszervezöknek. Közösségi játékok nem csak táborozóknak. Marczibányi Téri Müvelődési Központ, Budapest.

Trencsényi László és Papp György (I98I, szerk.): $K a$ landozások múltban és jövöben. Müvészeti táborok Csillebércen 1976-I980. Ifjúsági Lapkiadó Vállalat, Budapest.

Trencsényi László (I99I, szerk.): Világkerék. Komplex müvészetpedagógiai projektek az Iskolafejlesztési Központ gyüjteményéböl. OKI, Budapest.

Trencsényi László (2006,szerk.): A gyakorlati pedagógia néhány alapkérdése. Iskolán kívüli nevelés. ELTE PPK, Budapest.

Trencsényi László (2017): Partnerek és/vagy vetélytársak - a nevelés intézményrendszerének új megközelitése. Fapadoskönyv.hu, Budapest.

Úttörővezető újság: Tematika és keretjáték programok I985/5, 26.

Úttörővezető újság: Táborok (tematikus lapszám a táborozásról) I983/4. 